\title{
Effect of seeding methods and hatchery periods on sea cultivation of Saccharina latissima (Phaeophyceae): a Norwegian case study
}

\author{
Silje Forbord ${ }^{1,2}$ (I) $\cdot$ Kristine B. Steinhovden $^{2} \cdot$ Torfinn Solvang $^{2} \cdot$ Aleksander Handå $^{2} \cdot$ Jorunn Skjermo $^{2}$
}

Received: 5 July 2019 / Revised and accepted: 16 September 2019 / Published online: 23 October 2019

(C) The Author(s) 2019, corrected publication 2020

\begin{abstract}
To reach the goal of an industrialised macroalgae industry in Norway and other high-cost countries in the near future, a standardised seedling production method to improve quality control and predictability of cultivated biomass is essential. A total of 11 different treatments for seeding twine or rope with meiospores, gametophytes or juvenile sporophytes from the kelp Saccharina latissima were measured for growth (frond length, frond area, biomass yield and density) and protein content after 80 and 120 days at sea. Meiospore- and gametophyte-seeded twines were pre-cultivated in the hatchery for 14-42 days prior to deployment, while juvenile sporophytes of different ages were seeded on ropes directly on the day of deployment using a commercial binder to attach the seedlings. The results showed that seeding with meiospores pre-cultivated in the hatchery for 42 days (S42) before deployment gave significantly longer fronds $(77.0 \pm 6.7 \mathrm{~cm})$ and a higher biomass yield $\left(7.2 \pm 0.1 \mathrm{~kg} \mathrm{~m}^{-1}\right)$ at sea compared to other treatments. The poorest growth was measured for the direct-seeded sporophytes pre-cultivated in freefloating cultures for 35 days prior to deployment (D35; $34.4 \pm 2.4 \mathrm{~cm}$ frond length and $1.6 \pm 0.4 \mathrm{~kg} \mathrm{~m}^{-1}$ ). Image analysis was used to measure the coverage of the twine substrate before deployment, and a correlation was found between substrate coverage and frond length at sea, indicating that this can be used as a tool for quantity and quality control during the hatchery phase and before deployment. The protein content did not reveal any large differences between the treatments after 120 days of cultivation.
\end{abstract}

Keywords Cultivation strategies $\cdot$ Direct seeding $\cdot$ Kelp aquaculture $\cdot$ Image analysis $\cdot$ Optimising seaweed hatchery $\cdot$ Protein content

\section{Introduction}

The macroalga Saccharina latissima (Phaeophyceae) is one of the most attractive species for cultivation in the North Atlantic Ocean due to its fast growth and high content of valuable components (Holdt and Kraan 2011; Handå et al. 2013; Peteiro and Freire 2013; Sharma et al. 2018; Bak 2019). In 2017 Europe contributed less than $1000 \mathrm{t}$ of S. latissima to the global production of cultivated macroalgae of about 30 million $\mathrm{t}$ (Ferdouse et al. 2018), with China and other Asian

Silje Forbord

Silje.Forbord@sintef.no

1 Centre of Fisheries and Aquaculture, Department of Biology, Norwegian University of Science and Technology,

N-7491 Trondheim, Norway

2 SINTEF Ocean, Department of Environment and New Resources, N-7465 Trondheim, Norway countries supplying the major part of the biomass using breeding as a strategy to improve yield and quality ( $\mathrm{Wu}$ and Guangheng 1987; Zhang et al. 2007). Macroalgae for human consumption account for $83-90 \%$ of the value of the global market (Wei et al. 2013), and the Western market is expected to increase rapidly due to consumers' desire for new protein sources and healthy food supplements (Kim et al. 2017). This is a key driver for the ongoing development of an industrial macroalgae cultivation in Europe (Cottier-Cook et al. 2016), and high salary costs call for standardised solutions that are easy to scale up.

In aquaculture, seaweeds grow on artificial substrates or under free-floating conditions. Regardless of cultivation methods, land facilities are currently necessary to accommodate the hatchery units and facilities for the processing of harvested biomass. Although most cultivated macroalgae species can be grown through vegetative propagation, the production of seedlings is mandatory for several important commercial species. Saccharina latissima has a diplo-haplontic, heteromorphic life cycle 
with alternation between a microscopic haploid $(n)$ gametophyte generation and a macroscopic diploid (2n) sporophyte generation (Kain 1979). During the fertile season, a sorus with sporangia develops on the lamina and meiosis produces meiospores (spores) that are released into the surrounding water (Van Patten and Yarish 1993). The spores develop into female and male gametophytes, and fertilisation leads to the development of microscopic sporophytes that grow to adult size (Kain 1979). For any seaweed species grown through sexual reproduction, optimising hatchery production processes is crucial to the success of sea farming. Standardisation of cultivation procedures and strategies is essential to overcome low predictability of production quantity and quality, and to lower the production costs.

There are three main strategies for producing kelp seedlings, seeding the growth substrate with either (1) meiospores, (2) gametophytes or (3) juvenile sporophytes. Seedlings can be kept on a substrate in the hatchery for several weeks before deployment at sea or seeded directly before deployment using a binder.

Using spores for seeding requires fertile sporophytes, which is season-dependent if these are collected in natural habitats. Fertility can also be induced by artificial day rhythm and thus enable year-around access to spores (Pang and Lüning 2004; Forbord et al. 2012). Saccharina latissima development can be held in the gametophyte life stage (Zhang et al. 2008) by keeping the cultures in red light under controlled environmental conditions where fertilisation can be induced by changing from red to white light (Lüning and Dring 1972; Cuijuan et al. 2005). These continuous cultures are available for year-through seeding of gametophytes or production of juvenile sporophytes for direct seeding. This method can be advantageous as the use of incubation facilities might be shortened by several weeks or, in the case of direct seeding, omitted completely. The use of a binder to attach spores, gametophytes or sporophytes to the substrate is preferred by several commercial farmers and in research projects (Mols-Mortensen et al. 2017; Bak et al. 2018; Kerrison et al. 2018, 2019). Recent experiments have shown that a binder method of cultivation is not only as effective as traditional methods but also can be 100 times more space-efficient during the laboratory phase (Kerrison et al. 2018). When seeding spores or gametophytes on twine without using a binder, they need to be incubated in a hatchery for several weeks to be able to attach properly to the substrate before being deployed at sea (Xu et al. 2009; Forbord et al. 2018).

This study aimed to compare how three different seeding methods of $S$. latissima, using either meiospores, gametophytes or direct seeding with juvenile sporophytes, and time of hatchery periods affect growth in size (length and area), biomass yield, density and protein content during 80 and 120 days of sea cultivation.

\section{Materials and methods}

\section{Preparation of gametophyte cultures}

Sporophytes of S. latissima were collected by divers in August 2017 for induction of sori under low-light $(70 \mu \mathrm{mol}$ photons $\mathrm{m}^{-2} \mathrm{~s}^{-1}$ at the water surface)/short-day $(8 \mathrm{~h}$ light:16 h dark) conditions for 6 weeks before maturation according to Forbord et al. (2012). Sorus pieces from around 20 sporophytes were disinfected and dehydrated for $24 \mathrm{~h}$ at $4{ }^{\circ} \mathrm{C}$, and spore release was carried out the following day. The spore solution used for starting gametophyte cultures had a density of 400,000 spores $\mathrm{mL}^{-1}$, which was added to culture flasks with Provasoli's enriched seawater (PES) (Provasoli 1968) kept at $10{ }^{\circ} \mathrm{C}$ under constant red light with a light intensity of $30 \mu \mathrm{mol}$ photons $\mathrm{m}^{-2} \mathrm{~s}^{-1}$ and filtered air provided through silicon tubes for aeration. The cultures were up-scaled and maintained after 4 weeks and then every second week until used in the experiment in January 2018.

\section{Preparation of cultures of juvenile sporophytes for direct seeding}

Fertile S. latissima sporophytes were collected by divers in December 2017 and stored in tanks with running seawater and low-light/short-day conditions until used for different seeding trials in the current experiment. Sori tissue from around 20 sporophytes was used to obtain a spore solution with a density of $400,000-470,000$ spores $\mathrm{mL}^{-1}$ used for starting cultures of free-floating seedlings in aerated flasks containing PES at $10{ }^{\circ} \mathrm{C}$ in white light $\left(40 \mu \mathrm{mol}\right.$ photons $\left.\mathrm{m}^{-2} \mathrm{~s}^{-1}\right)$ and a light regime of $16 \mathrm{~h}$ light: $8 \mathrm{~h}$ dark to promote fertilisation and sporophyte development. Cultures were started 42 (D42), 35 (D35) and 28 (D28) days before they were seeded on ropes using a binder and deployed at sea the same day. The seedlings had an average length of $45-120 \mu \mathrm{m}$ before seeding, and the fraction of sporophytes vs. gametophytes was in the range of $7.4-13.6 \%$ where one counted individual was equal to one sporophyte or one gametophyte filament (Table 1). The sporophyte cultures were diluted $50 / 50$ with autoclaved seawater to aim for the same density as the spore solutions. One of the gametophyte culture was induced in white light for 14 days (GF0) before being seeded with the binder directly on ropes on the day of deployment and had an average length of $88 \mu \mathrm{m}$ and a sporophyte vs. gametophyte fraction of $6.4 \%$. A commercial binder (AtSeaNova, BE) was used to thicken the sporophyte/gametophyte cultures, which were applied to the ropes ( $\varnothing 18 \mathrm{~mm}$, braided AlgaeRope), preventing the suspended seedlings from being washed off before they could attach (Kerrison et al. 2018). The protocol for 
Table 1 Detailed information for the different hatchery treatments before deployment in sea showing their abbreviation (Abb), the starting dates for cultures and for induction of fertility in white light, the culture

\begin{tabular}{|c|c|c|c|c|c|c|}
\hline $\begin{array}{l}\text { Hatchery } \\
\text { treatment }\end{array}$ & $\mathrm{Abb}$ & $\begin{array}{l}\text { Date of culture start/date of } \\
\text { fertility induction }\end{array}$ & $\begin{array}{l}\text { Culture density } \\
\left(\text { spores } \mathrm{mL}^{-1} \text { ) }\right.\end{array}$ & $\begin{array}{l}\text { Date for } \\
\text { seeding on } \\
\text { ropes }\end{array}$ & $\begin{array}{l}\text { Seeding density (spores } \mathrm{mL}^{-1}, * m g \mathrm{~mL}^{-1} \\
\text { (DW) or **individuals } \mathrm{mL}^{-1} \text { ) }\end{array}$ & $\begin{array}{l}\text { Length at } \\
\text { seeding }(\mu \mathrm{m})\end{array}$ \\
\hline Spores 42 & $\mathrm{~S} 42$ & - & - & 03.01 .18 & 250,000 & - \\
\hline Spores 28 & $\mathrm{~S} 28$ & - & - & 17.01.18 & 250,000 & - \\
\hline Spores 21 & $\mathrm{~S} 21$ & - & - & 24.01 .18 & 250,000 & - \\
\hline $\begin{array}{l}\text { Gametophytes } \\
28\end{array}$ & G28 & 06.10 .17 & 400,000 & 17.01 .18 & $* 0.35$ & - \\
\hline $\begin{array}{l}\text { Gametophytes } \\
21\end{array}$ & G21 & 06.10 .17 & 400,000 & 24.01 .18 & $* 0.35$ & - \\
\hline $\begin{array}{l}\text { Gametophytes } \\
14\end{array}$ & G14 & 06.10 .17 & 400,000 & 31.01 .18 & $* 0.35$ & - \\
\hline $\begin{array}{l}\text { Gametophytes } \\
\text { fertile } 14\end{array}$ & GF14 & $06.10 .17 / 17.01 .18$ & 400,000 & 31.01 .18 & $* 0.35$ & - \\
\hline $\begin{array}{l}\text { Gametophytes } \\
\quad \text { fertile direct } 0\end{array}$ & GF0 & $06.10 .17 / 31.01 .18$ & 400,000 & 13.02 .18 & $\begin{array}{l}\text { **Gametophytes: } 2805 \\
* * \text { Spores: } 180\end{array}$ & 87.6 \\
\hline $\begin{array}{l}\text { Sporophytes } \\
\quad \text { direct } 42\end{array}$ & D42 & 03.01 .18 & 434,000 & 13.02 .18 & $\begin{array}{l}* * \text { Gametophytes: } 1740 \\
* * \text { Spores: } 185\end{array}$ & 92.4 \\
\hline $\begin{array}{l}\text { Sporophytes } \\
\text { direct } 35\end{array}$ & D35 & 10.01 .18 & 400,000 & 13.02 .18 & $\begin{array}{l}* * \text { Gametophytes: } 5973 \\
* * \text { Spores: } 440\end{array}$ & 44.5 \\
\hline $\begin{array}{l}\text { Sporophytes } \\
\text { direct } 28\end{array}$ & D28 & 17.01.18 & 467,000 & 13.02 .18 & $\begin{array}{l}* * \text { Gametophytes: } 1730 \\
* * \text { Spores: } 235\end{array}$ & 120.0 \\
\hline
\end{tabular}
spores, $\mathrm{mg} \mathrm{mL}^{-1}$ (DW) for gametophytes and individuals $\mathrm{mL}^{-1}$ for sporophytes) and the sporophyte lengths at seeding density, the date of seeding on ropes, the seeding density (spores $\mathrm{mL}^{-1}$ for seeding with the binder is IPR of the AT SEA project partners (http://www.atsea-project.eu/).

\section{Seeding of meiospores and gametophytes on twine in the hatchery}

The spore solution used for producing seedlings on twine had a density of 250,000 spores $\mathrm{mL}^{-1}$ (Table 1). Gametophytes used for seeding were either taken straight from the red-light conditions or induced for 14 days in white light to make the gametophytes fertile before seeding. The gametophyte densities were measured with optical density at $750 \mathrm{~nm}\left(\mathrm{OD}_{750}\right)$ and diluted to $0.35 \mathrm{mg} \mathrm{mL}^{-1}$ (DW) before seeding (OD calculated to DW from standard curves), a density found to give adequate seedling growth on substrate in previous experiments with Alaria esculenta (Duarte 2017). Spores and gametophytes were seeded on $\varnothing 1.2 \mathrm{~mm}$ twisted nylon string coiled around PVC spools. The spools were incubated in 300-L cylinders holding running, nutrient-rich deep water, a light intensity of $70 \mu \mathrm{mol}$ photons $\mathrm{m}^{-2} \mathrm{~s}^{-1}$ outside the cylinders and a light regime of 16:8 (L:D). To let the propagules settle on the twine, the water was kept stagnant before a water flow of around $2 \mathrm{~L} \min ^{-1}$ and aeration was turned on 3 days after seeding. Seeding with spores started 42 (S42), 28 (S28) and 21 (S21) days before deployment, and gametophytes were seeded 28 (G28), 21 (G21) and 14 (G14) days before deployment (Table 1). One culture of gametophytes was induced in white light for 14 days before being seeded on twine and kept in the hatchery for 14 days before deployment (GF14). Details concerning all stages of seedling production are described in Forbord et al. (2018).

\section{Substrate coverage measured by image analysis}

To quantify the number of seedlings covering the twine substrate, images were collected 2 days prior to deployment at sea for later processing. The cylinders with the twine substrate were removed from the incubators into a small water-filled glass tank for depiction. A white LED ring light (Effilux 000 SD P2) was used for even illumination in a brightfield setup with the lens positioned inside the ring light. Each substrate cylinder was depicted at three distinct locations, resulting in three images per substrate (Alver et al. 2018). The working distance was kept identical between images, and the field of view was $30 \times 40 \mathrm{~mm}$. Images were collected using a Nikon D800E DSLR and a Sigma AF $105 \mathrm{~mm} \mathrm{f/2,8} \mathrm{macro} \mathrm{lens.}$ Software was developed in LabVIEW (National Instruments Co., USA), which extracted the saturation colour plane to identify seedlings on the white substrate. The International Commission on Illumination has defined six attributes describing a colour, saturation being one of them, defined as the colourfulness of an area relative to its brightness (CIE Standard S 017/E 2011). Using the saturation colour plane is a robust method of segmenting the growth from the cultivation substrate. The average pixel intensity from the saturation colour plane of the three images per cylinder is calculated to 
represent the amount of growth using the developed software. The values presented here were normalised to a percentage of the output range, where $0 \%$ is a clean, white substrate and $100 \%$ is a substrate completely covered by sporophytes.

\section{Deployment at sea, growth measurements and collection of samples for chemical analysis}

The seed lines were entwined onto 6-m-long $18-\mathrm{mm}$ carrier ropes using a spinning machine on the day of deployment (Alver et al. 2018; Forbord et al. 2018) and randomly distributed vertically from two longlines at the sea farm Skarvøya in Central Norway $\left(63^{\circ} 39^{\prime} \mathrm{N}, 8^{\circ} 39^{\prime} \mathrm{E}\right)$ on 13 February 2018 (Fig. 1). This area has a mild maritime climate with the coldest season from January to March and the driest season in May to June (Sharma et al. 2018). The farm is sited at a sheltered location. The first registration was done on 4 May 2018 after 80 days at sea and the last one on 13 June 2018 after 120 days at sea. Length and width measurements of 20 sporophytes for all treatments on each of the two longlines were registered in May and June, and biomass and density were measured only in June, all from 1 to $2 \mathrm{~m}$ cultivation depth. Samples of 10 individuals, consisting of frond, stipe and holdfast, from all treatments at both lines, were collected for chemical analysis and kept cold in bags until frozen at $-20{ }^{\circ} \mathrm{C}$ immediately after arriving at the laboratory (Fig. 1).

The relative daily growth rate $\left(\mathrm{RGR}, \mathrm{day}^{-1}\right)$ based on an increase of mean frond length was calculated as
$\operatorname{RGR}\left(\operatorname{day}^{-1}\right)=\frac{\left(\frac{L_{1}-L_{0}}{T}\right)}{L_{0}}$

where $L_{1}$ represents length $(\mathrm{cm})$ at a given sampling date, $L_{0}$ the length $(\mathrm{cm})$ at the previous sampling date and $T$ is the elapsed time (days) between these sampling days.

The area of the sporophytes was calculated using a factor of $0.75 \times$ length $\times$ width $($ Broch et al. 2013).

\section{Temperature}

The temperature was recorded at $2 \mathrm{~m}$ depth every $15 \mathrm{mins}$ using Onset HOBO pendant loggers (Bourne, USA; temperature accuracy $\pm 0.53{ }^{\circ} \mathrm{C}$, resolution $0.14{ }^{\circ} \mathrm{C}$ ) situated on a separate rope placed in the middle of the farm. The loggers were cleaned from fouling during the May registration.

\section{Nitrogen analysis}

Nitrogen content was analysed for the whole thalli. The samples were frozen at $-20^{\circ} \mathrm{C}$ and later stored at $-80{ }^{\circ} \mathrm{C}$ until freeze-dried (Hetosicc CD 13-2) at $-40{ }^{\circ} \mathrm{C}$ for $48 \mathrm{~h}$. The freeze-dried kelp was homogenised into a fine powder; samples of $0.4-1.0 \mathrm{mg}$ were transferred to tin capsules, and nitrogen was analysed in parallels with a Carlo Erba element analyser (model 1106). The nitrogen content was used to calculate the protein content using season- and depth-specific
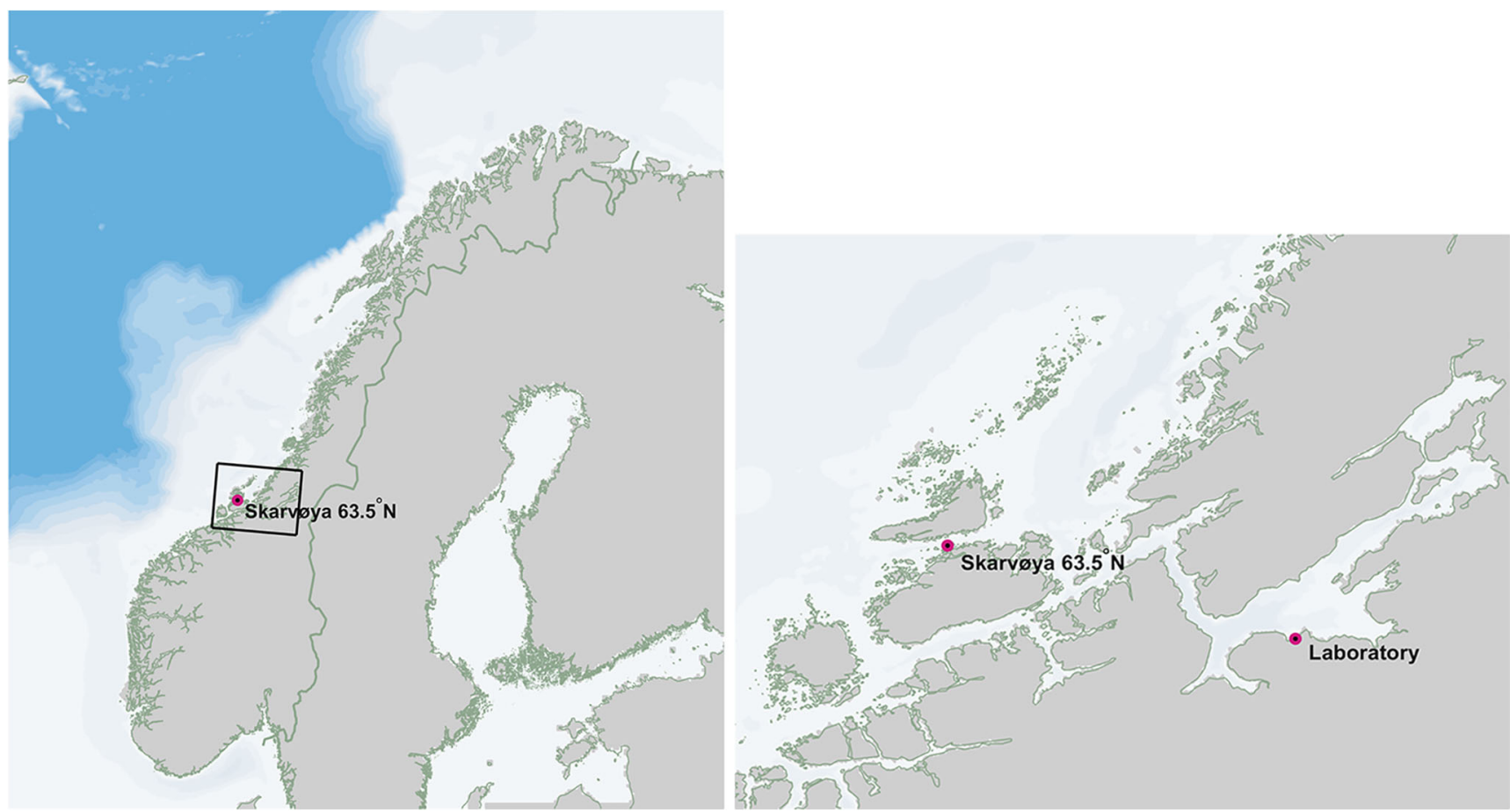

Fig. 1 Geographical location of the experimental seaweed farm Skarvøya and the laboratory producing the seed lines. The region to the right is indicated by a black rectangle in the large-scale map 
nitrogen-to-protein conversion factors $\left(K_{\mathrm{p}}\right)$ of 3.6 for May and 4.3 for June (Forbord et al. submitted).

\section{Statistics and data analyses}

Independent-samples $t$ tests were run to assess if there were differences between frond length and width between the two long lines after confirming the assumption of normality (Shapiro-Wilk's test) and homogeneity of variance (Levene's test). Significant differences were not found between any of the 11 treatments on the two lines, and the lines were pooled to get a sample size of $n=40$. For frond length and sporophyte area, the assumption of homogeneity of variances was violated (Levene's test, $p<0.001$ ). The Welsh ANOVA was used to look for significant differences and the Games-Howell post hoc test to compare all possible combinations of group differences. Linear regression analysis was performed to look for the relationship between density and individual sporophyte weight, and for mean frond length and the substrate coverage before deployment. Data are presented as mean \pm standard error (SE) unless otherwise stated. Significance level was set to 0.05 . Statistical analysis was performed using IBM SPSS Statistical Software (Version 25), and plots were made using Systat SigmaPlot software (version 14).

\section{Results}

\section{Substrate coverage before deployment at sea}

The treatment showing the highest substrate coverage was the spore treatment S42 with an average of $84 \%$ (Figs. 2 and 3). This treatment had the longest incubation time of 42 days in the hatchery before deployment at sea. S28 and S21 had a coverage of $58 \%$ and $25 \%$, respectively. For the gametophyte

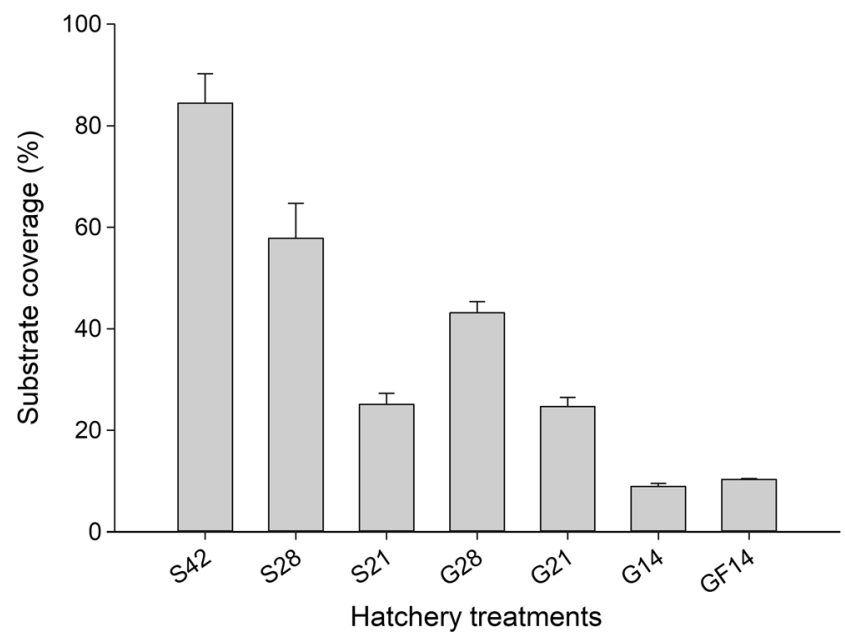

Fig. 2 Substrate coverage (\%) before deployment of spore and gametophyte treatments on twine (see Table 1) incubated in the hatchery for $14-42$ days. Mean $\pm \mathrm{SD}, n=3$ seeding, the G28 treatment with 28 days of incubation had a substrate coverage of $43 \%$ on average compared to G21 and G14 with $25 \%$ and $9 \%$ coverage, respectively. The GF14 treatment that was induced in white light before seeding and incubated in the hatchery for the same number of days as the G14 treatment had a coverage of $10 \%$.

\section{Temperature}

The sea temperature was at its lowest in mid-March at $4.5^{\circ} \mathrm{C}$ and at its highest at the beginning of June at $10.2{ }^{\circ} \mathrm{C}$ (Fig. 4). Average monthly temperatures never reached more than $9.8^{\circ} \mathrm{C}$.

\section{Growth performance at sea}

Mean frond lengths of S. latissima varied pronouncedly between treatments, and a pattern was apparent where the treatments with a long hatchery period had longer fronds than the treatments with a shorter period in the hatchery (Fig. 5). The mean maximum frond length in June of $77.0 \pm 6.7 \mathrm{~cm}$ was found for treatment S42, while the shortest fronds were found for treatment D35 with $34.4 \pm 2.4 \mathrm{~cm}$. The $\mathrm{S} 42$ sporophytes were significantly longer than the other treatments in both May (Welch's $F_{10,170.2}=48.7, p<0.001$ ) and June (Welch's $\left.F_{10,171.2}=20.4, p<0.001\right)$.

Generally, the direct-seeded treatments (GF0, D42, D35 and D28) showed higher relative growth rates (RGR, day ${ }^{-1}$ ) between the two registrations than the spore- and gametophyte-seeded treatments. The RGR for all treatments fluctuated around 0.02-0.05 day ${ }^{-1}$ (Fig. 5).

The relationship between mean frond length $(\mathrm{cm})$ and the substrate coverage $(\%)$ before deployment revealed a strong positive correlation for both May $(r=0.84)$ and June $(r=$ 0.90). Linear regression was used to fit straight lines to the data (Fig. 6), and the linear association reached statistical significance for both May $\left(R^{2}=0.7, F_{1,5}=11.8, p=0.018\right)$ and June $\left(R^{2}=0.8, F_{1,5}=20.7, p=0.006\right)$, with a slightly better fit for June than for May.

The highest mean frond area in June was found for treatment S42 with $588 \pm 52.4 \mathrm{~cm}^{2}$, and the lowest was measured for D35 with $133 \pm 11.8 \mathrm{~cm}^{2}$ (Fig. 7). The S42, S28, G28 and G21 sporophytes had a significantly larger area than the other treatments in May (Welch's $F_{10,165.95}=43.1, p<0.001$ ), and in June, the S42 and G28 sporophytes showed a significantly larger area than the other treatments (Welch's $F_{10,170.3}=19.5$, $p<0.001)$.

Biomass yield $\left(\mathrm{kg} \mathrm{m}^{-1}\right)$ and sporophyte density (individuals $\mathrm{m}^{-1}$ ) were measured in June, and as no fouling by diatoms and filamentous algae was visible, the weight represents only kelp biomass. The mean biomass yield across all treatments was $3.4 \pm 0.5 \mathrm{~kg} \mathrm{~m}^{-1}$, and the range was from $1.6 \pm$ 0.4 for D35 to $7.2 \pm 0.1 \mathrm{~kg} \mathrm{~m}^{-1}$ for the S24 treatment (Fig. 8a). 

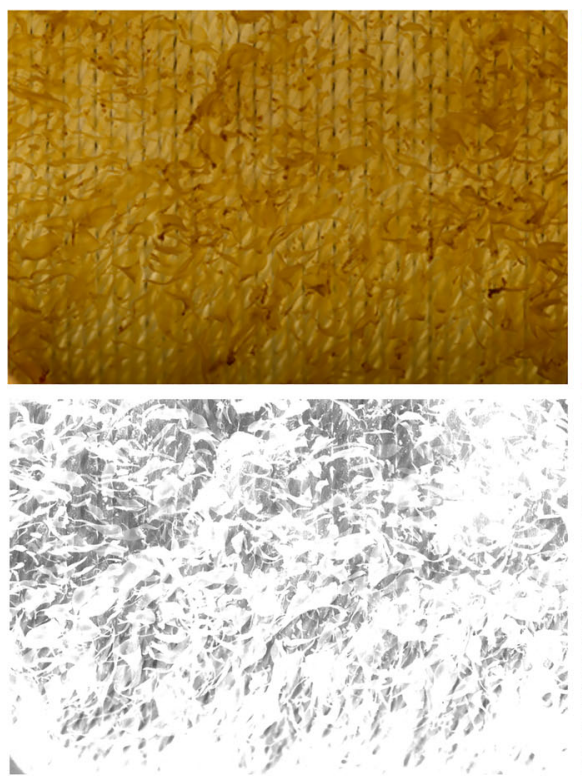

S42

Coverage: $84 \%$
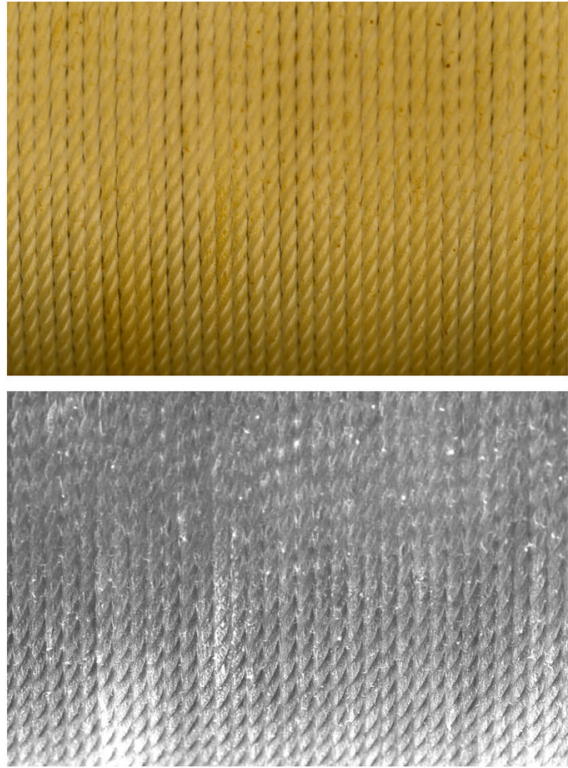

S28

Coverage: $58 \%$
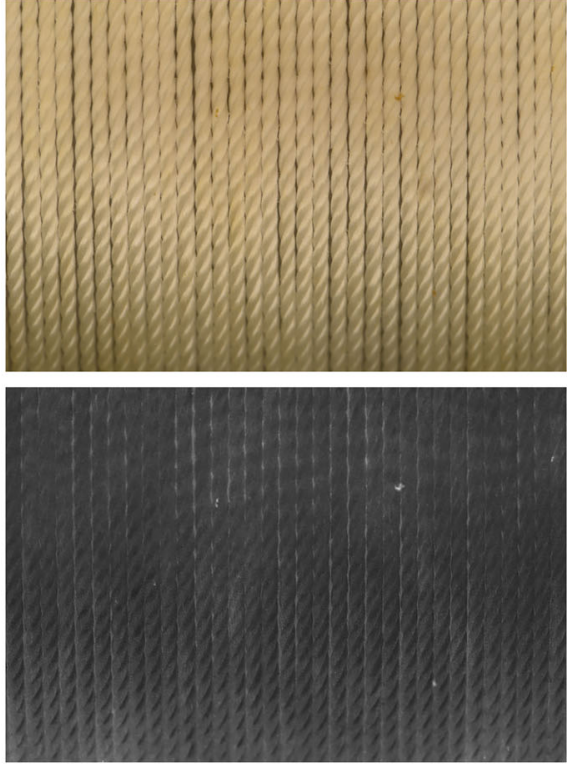

S21

Coverage: $25 \%$

Fig. 3 Colour images of substrate (top row) and corresponding saturation image planes (bottom row). Treatment S42 (left) had an average substrate coverage of $84 \%$, treatment S28 (mid) with an average substrate coverage of 58\% and treatment S21 (right) with an average substrate coverage of 25\%

The sporophyte density had a mean value across all treatments of $311 \pm 87.9$ individuals $\mathrm{m}^{-1}$ and was lowest for the $\mathrm{G} 28$ treatment with $175 \pm 5.0$ individuals $\mathrm{m}^{-1}$ compared to the highest density of $450 \pm 35.4$ individuals $\mathrm{m}^{-1}$ for the D35 treatment (Fig. 8b).

The relationship between sporophyte density and the individual sporophyte weight revealed a linear increase of individual weight with decreasing density with a positive correlation ( $r=0.73$ ) (Fig. 9). Linear regression was used to fit a straight line to the data, and the linear association reached statistical significance $\left(R^{2}=0.5, F_{1,9}=10.0, p=0.012\right)$. The results from the S42 treatment (marked with a circle in Fig. 9) deviated strongly from the others, having both a high density $\left(417 \pm 31.8\right.$ individuals $\left.\mathrm{m}^{-1}\right)$ and high individual weight $(8.7$

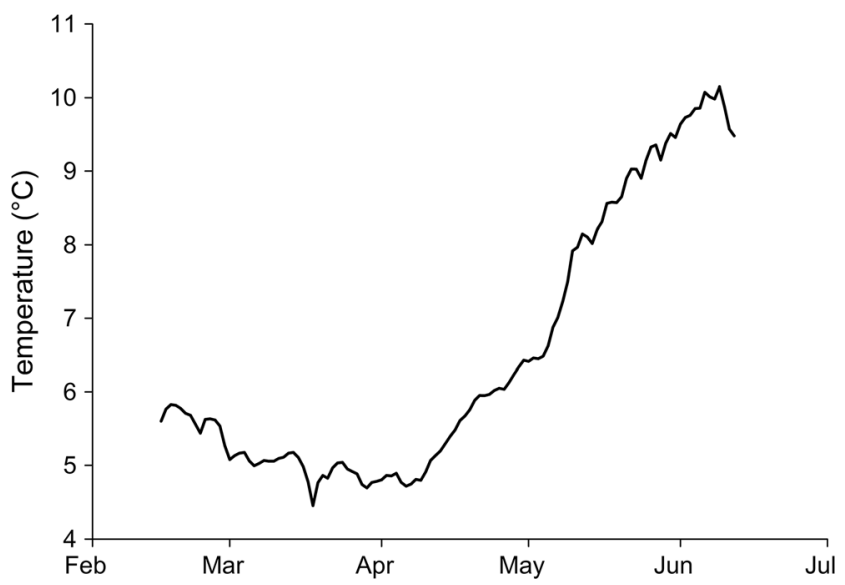

Fig. 4 Daily average sea temperatures $\left({ }^{\circ} \mathrm{C}\right)$ at $2 \mathrm{~m}$ depth at the sea farm Skarvøya from deployment in mid-February until harvest in mid-June $\pm 0.6 \mathrm{~g})$. With the removal of this treatment from the linear regression, the positive correlation was strong $(r=0.95)$, with a significant linear association $\left(R^{2}=0.9, F_{1,8}=73.5\right.$, $p<0.001)$.

\section{Protein content}

The protein content decreased from May to June for all treatments (Fig. 10), and the mean content across all treatments was $73.3 \pm 2.4 \mathrm{mg} \mathrm{g}^{-1} \mathrm{DW}$ in May and $57.2 \pm 1.5 \mathrm{mg} \mathrm{g}^{-1} \mathrm{DW}$ in June. In May, the highest protein content was found for the G21 sporophytes with $87.0 \pm 5.3 \mathrm{mg} \mathrm{g}^{-1} \mathrm{DW}$, and in June, the highest content was measured in the G14 treatment with 67.3 $\pm 2.6 \mathrm{mg} \mathrm{g}^{-1} \mathrm{DW}$. Overall, the protein content did not vary a lot between the 11 different treatments over the cultivation period.

\section{Discussion}

Building up a full-scale seaweed hatchery can constitute a high investment cost for farmers and might not be manageable for newly established companies. A shortening of the incubation phase, thus enabling several production cycles or a total omittance, might therefore be worth looking into, especially when aiming for large-scale cultivation to reach the prospected production goals of 4 million $t$ of macroalgae in Norway in 2030 and 20 million t in 2050 (Olafsen et al. 2012). 
Fig. 5 Frond length for May and June sampling (left $y$-axis) and RGR (right $y$-axis) for the different hatchery treatments (see Table 1), mean \pm SE, $n=40$. Letters above bars denote significant differences in length between the treatments, lowercase letters for May and capital letters for June

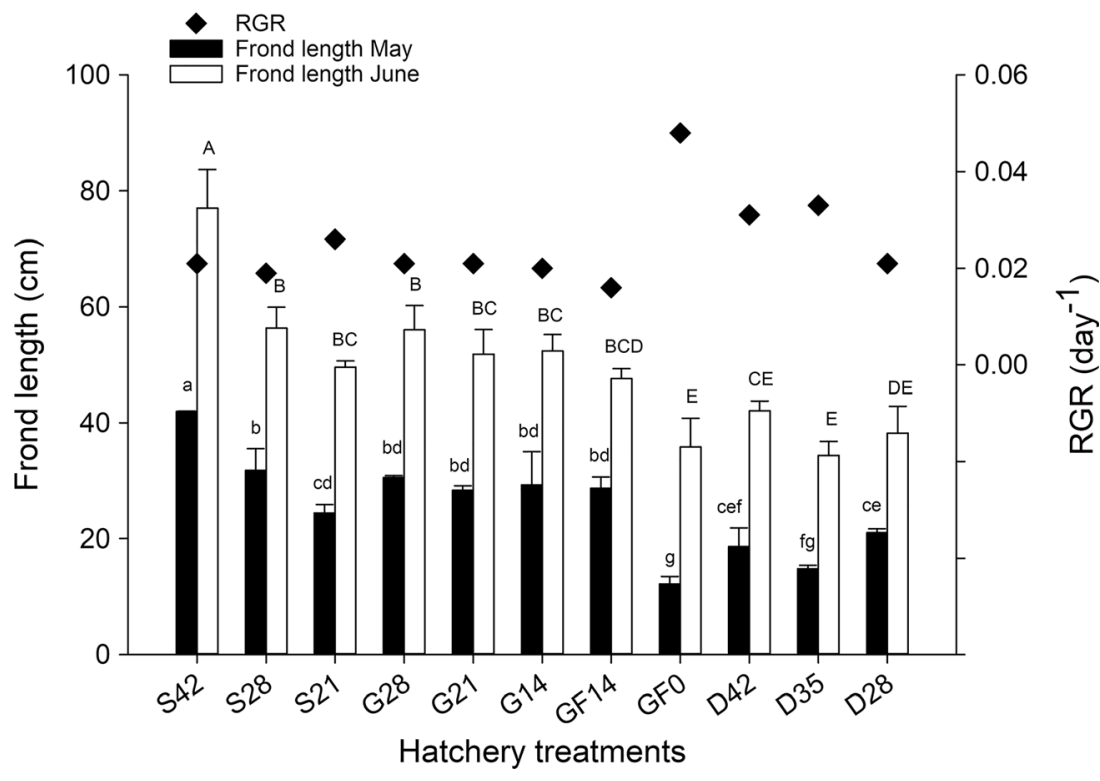

\section{Image analysis of substrate coverage before deployment at sea}

Standardisation of production methods to improve quality control and predictability of produced quantity of seaweed biomass is needed for upscaling to industrial production volumes of macroalgae in high-cost countries, e.g. in Western Europe. Monitoring, automation and control techniques are necessary to replace manpower. In this study, we demonstrate a possible first step through the measurement of the substrate coverage as a form of early-stage control of the seedling quality and expected quantity of produced biomass. The method makes processing of a large number of images possible with little effort, compared to manual counting/analysis of the substrate itself or images of it. However, a weak point of this method is to separate the growth of target species from that of other contaminant species like diatoms or filamentous

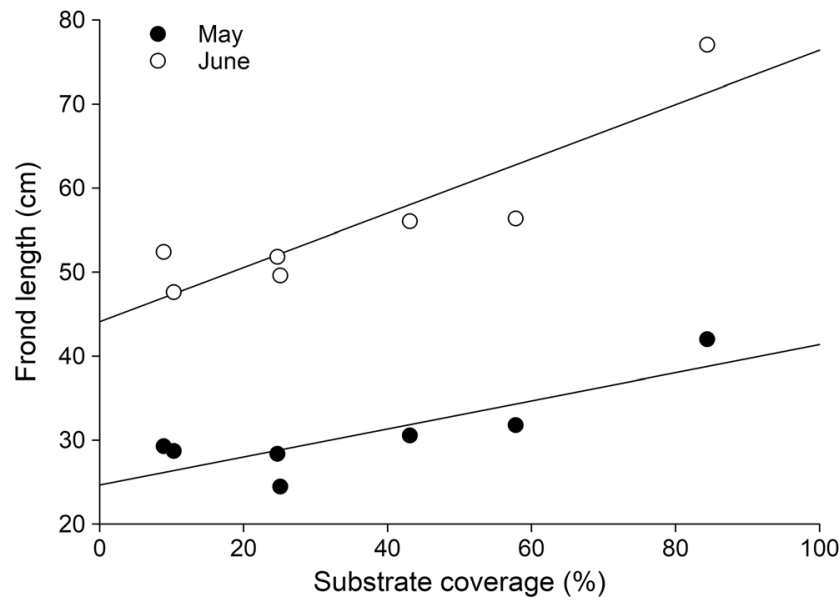

Fig. 6 The mean frond length $(\mathrm{cm})$ for May and June as a function of the substrate coverage $(\%)$ at deployment in sea in February, with regression lines showing the linear trends algae. If these species have a somewhat similar colour representation, contamination may be hard to distinguish from target species using image processing techniques. Although the measured growth may be correct using the saturation method presented here, it may not be accurately represented for the targeted species if unwanted species are increasingly present. The method may be refined, and one step in that direction would involve the calibration of reflectance from a standard target, as light quality, intensity and sensitivity in the source and camera are due to change between equipment and time. The light-reflecting properties of the substrate influence the definition of zero coverage, and hence, this should also be included in the calibration process. A comparison of the method against the manual counting of sporophytes on substrate was not within the scope of the experiment.

\section{Growth performance at sea}

All the 11 seeding treatments were cultivated successfully at sea but with significant differences in frond lengths. The overall best performance of all measured variables was obtained by seeding twine with spores and pre-cultivating them in the hatchery for 42 days (S42), a treatment used in previous experiments in Norway (Forbord et al. 2012; Handå et al. 2013; Fossberg et al. 2018; Sharma et al. 2018). Frond lengths in June for the S42 treatment were comparable to those of previous experiments in the Faroe Island and Norway (Handå et al. 2013; Mols-Mortensen et al. 2017; Bak et al. 2018), and the biomass was well within the range found by other trials in Europe (Peteiro and Freire 2009; Kraan 2013; MolsMortensen et al. 2017; Matsson et al. 2019). The D35 treatment, on the contrary, showed the shortest frond lengths and the lowest biomass yield, which was in the same range or higher as found in several Danish cultivation experiments 
Fig. 7 Mean frond area $\left(\mathrm{cm}^{2}\right)$ for May and June sampling for the different hatchery treatments (see Table 1), mean \pm SE, $n=40$.

Letters above bars denote significant differences between the treatments, lowercase letters for May and capital letters for June

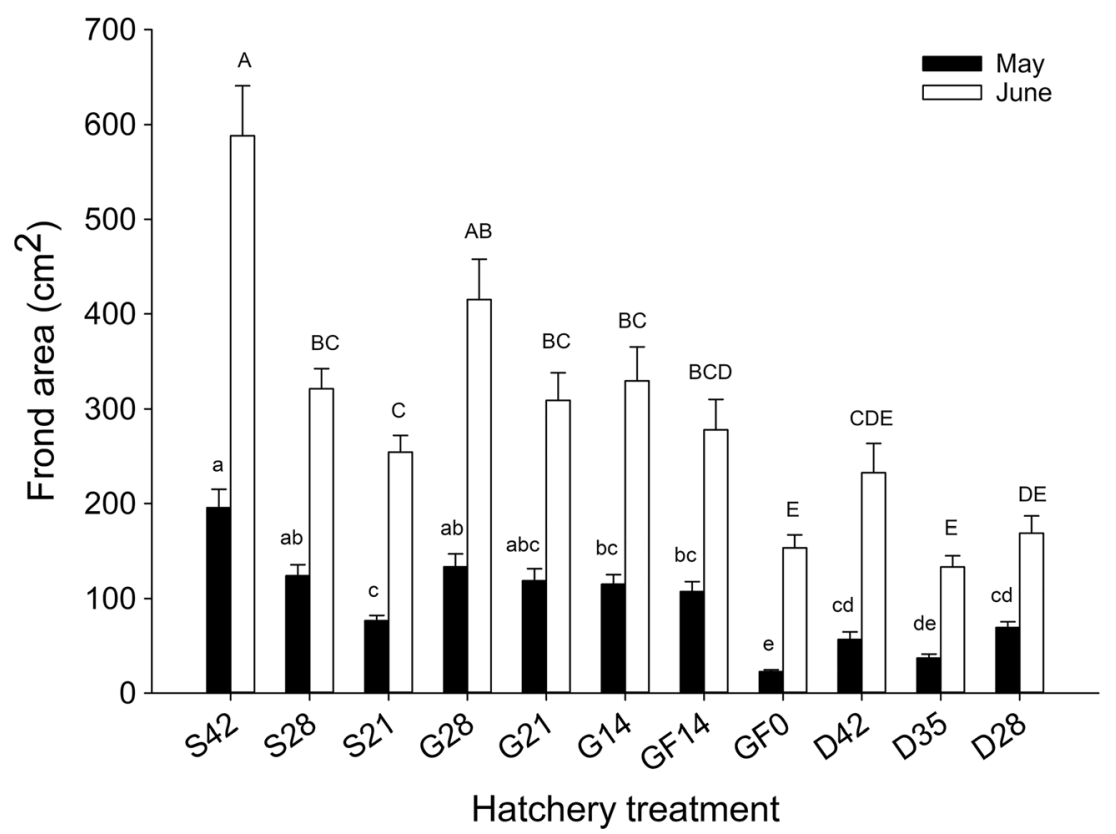

(Marinho et al. 2015; Bruhn et al. 2016). All treatments in the current experiment resulted in shorter fronds than those found in a previous cultivation experiment in the same geographical area but at a more exposed location (Sharma et al. 2018). They found average lengths twice of the best growth in the present experiment after 134 days at sea, suggesting that local environmental conditions have a major impact on the growth at sea.

The frond area showed a similar trend as the length in June with the highest measured values for the S42 treatment and the lowest for D35, indicating that the width of the frond mainly followed the frond length at this sheltered location. Both the area and length of S. latissima have been found to give good estimates for the standing biomass (Stagnol et al. 2016; Foldal 2018).

The highest relative growth rate (RGR) for the cultivation period was found for the four direct-seeded treatments (GF0,

a)

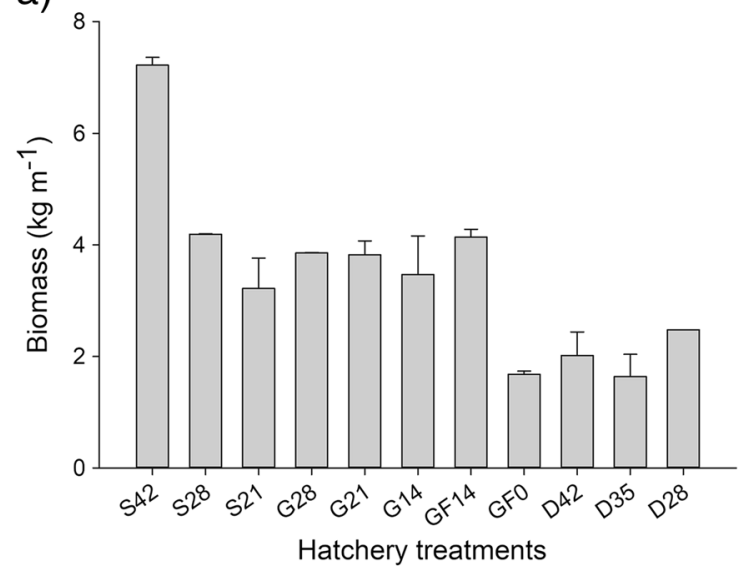

D42, D35, D28), which had the shortest frond lengths compared to the others after 80 and 120 days at sea. This is explained by growth rates becoming reduced with increasing size of the sporophytes (Huges 1973; Kain 1991).

Sporophyte density on ropes can affect individual sporophyte growth and total yield (Reed et al. 1991; Creed et al. 1998; Steen and Scrosati 2004; Kerrison et al. 2015, 2016). The optimal density for the highest achievable biomass yield for S. latissima and other kelp species is, however, still unknown (Kerrison et al. 2015). The sporophyte density varied greatly between the treatments in the current experiment, with an almost three times higher density for D35 compared with G28, suggesting a better attachment to the substrate (Xu et al. 2009; Kerrison et al. 2018). The sporophyte density had a strong correlation with the individual sporophyte weight, showing that high densities led to low individual weights due to intraspecific competition and resource limitation such

b)

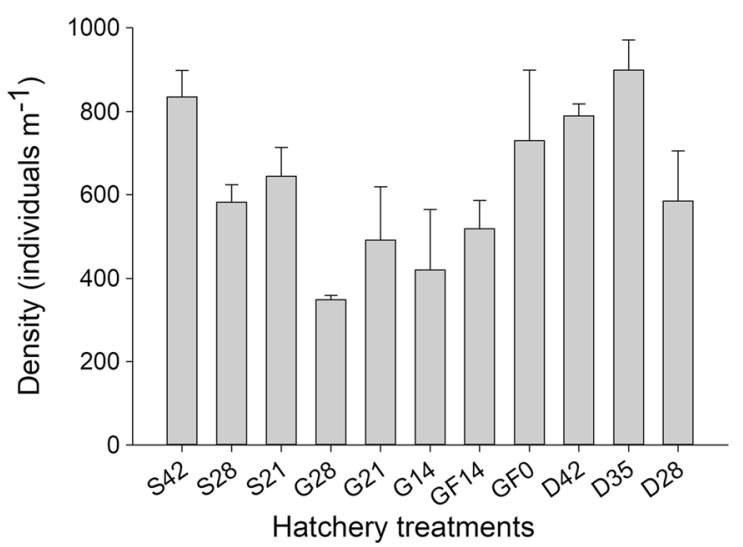

Fig. 8 a Biomass yield $\left(\mathrm{kg} \mathrm{m}^{-1}\right)$ and $\mathbf{b}$ sporophyte density (individuals $\mathrm{m}^{-1}$ ) for the different hatchery treatments (see Table 1) in June, mean \pm SE, $n=2$ 


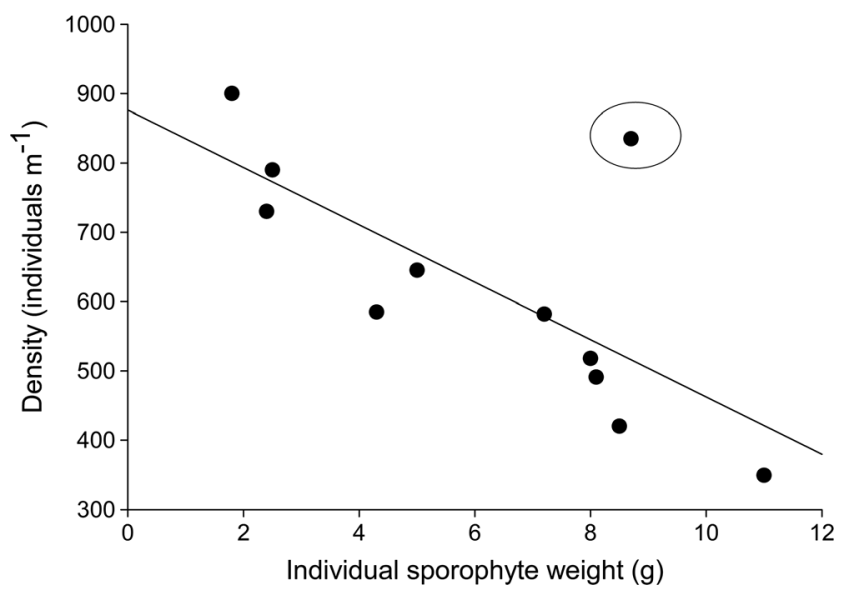

Fig. 9 The sporophyte density on the ropes (individuals $\mathrm{m}^{-1}$ ) as a function of the individual sporophyte weight $(\mathrm{g})$, with the regression line showing the linear trend. The S42 treatment deviated from the others with both high density and weight and is marked with a circle

as light and nutrients (Kain and Jones 1963). However, the only treatment deviated from this linear trend was the S42 with the highest yield but also one of the highest densities. One possible explanation for this can be that the long incubation period in the hatchery before deployment stimulated the development into sporophytes from a higher number of spores, but the high density obviously did not exceed the optimal density for growth at sea.

All 11 treatments were deployed the same day on the same farm and were exposed to the same environmental conditions during sea cultivation. Differences in growth performance were, therefore, most likely attributed to the size and density of the juvenile sporophytes at deployment. The range in temperature measured during the experiment showed that the treatments were cultured within the typical thermal range of $5-15{ }^{\circ} \mathrm{C}$ for $S$. latissima (Kerrison et al. 2015) and never

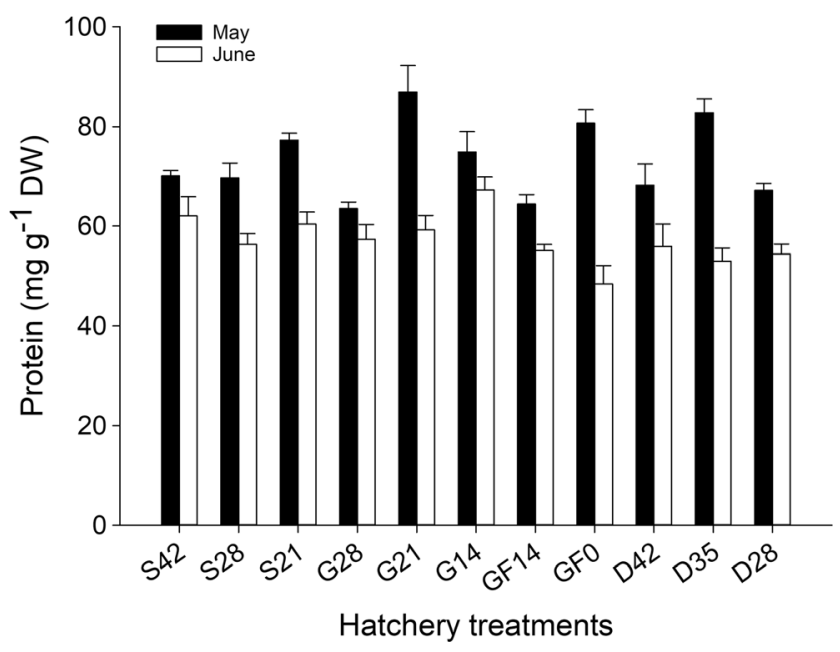

Fig. 10 Protein content $\left(\mathrm{mg} \mathrm{g}^{-1} \mathrm{DW}\right)$ as $[\mathrm{N}] \times 3.6$ in May and $[\mathrm{N}] \times 4.3$ in June for different hatchery treatments (see Table 1), mean \pm SE, $n=2$ encountered temperatures exceeding $17{ }^{\circ} \mathrm{C}$ that may cause loss of tissue (Gerard et al. 1987).

\section{Comparing similar seeding methods}

By comparing growth performance at sea for treatments with the same seeding method (spores, gametophytes or juvenile sporophytes), a clear pattern was seen for spores (S42, S28 and S21), with a significantly increased growth at sea with number of days in the hatchery. This was also evident from the substrate coverage before deployment with a decrease from $84 \%$ for S42, 58\% for S28 and 25\% coverage for S21. For seeding with gametophytes (G28, G21, G14 and GF14), on the contrary, no significant differences were found at sea with days in the hatchery. However, a difference in the substrate coverage could be seen with the G28 having $43 \%$ coverage, the G21 25\% and the G14 and the GF14 9 and 10\% coverage, respectively. A clear correlation between the substrate coverage and frond length for all twine seeded treatments was found for both the May and June samplings, suggesting that image analysis can be used as a tool for easy quantification of frond lengths and quality assurance of the seed lines before deployment. The four direct-seeded treatments (GF0, D42, D35 and D28) showed the poorest growth at sea for all measured variables and no significant differences with seedling age. Seedling lengths and share of developed sporophytes compared to gametophytes in the free-floating cultures did not follow an age-specific pattern. This could be due to small and stochastic differences in spore development in the free-floating cultures caused by genetic variation, a different maturation degree of the selected sori, self-shading or minor different physical conditions like light and aeration. However, a clear coherence between the seedling's length at deployment and growth performance at sea was evident for the D35 treatment that had the poorest growth for all measurements in this study and that deviated most from the robust S42 treatment.

\section{Comparing treatments of similar age}

The gametophytes were at a more advanced stage in the development than spores when seeded on twine, but they usually need 8-10 days in white light before reaching fertility (Arbona and Molla 2006) and time to develop rhizoids to attach properly to the substrate in contrast to spores that actively attach (Xu et al. 2009). The substrate coverage before deployment at sea for treatments S28 vs. G28 and S21 vs. G21, which had the same number of days in the hatchery, was comparable. When comparing these treatments at sea after 120 days of cultivation, they had the same frond lengths and biomass yield, but the spore-seeded twine had a higher density than the gametophyte-seeded twine, most likely due to poorer adhesion properties of the gametophytes (Xu et al. 2009; Shan 
et al. 2013). Loss of propagules after seeding and placement in the incubators could thus be a possible explanation for the gametophyte treatments resulting in the lowest density at sea. Techniques to avoid this can be disrupting the gametophyte fragments as small as possible for better attachment, increasing the period of stagnant water in the incubators $(\mathrm{Xu}$ et al. 2009) or using a binder for better attachment (Kerrison et al. 2018). The gametophytes transferred to white light for induction of gametogenesis (GF14) 14 days prior to seeding did not show a significantly better length growth at sea than the gametophytes seeded directly from red-light conditions (G14), indicating that the fertility induction in white light in reality can be omitted for S. latissima gametophytes.

\section{Direct seeding}

Gluing juvenile sporophytes or gametophytes directly on to the droplines before deployment using a binder saves both time and space by skipping the hatchery incubation and the time-consuming entwining process of the seed string onto the droplines. When cultivating juvenile sporophytes in freefloating cultures, the holdfast of the sporophytes will most likely not develop as rapidly as when pre-cultivated on substrates in a hatchery for several weeks prior to deployment at sea. Mols-Mortensen et al. (2017) explained low yields using a binder method by a possible detachment of the seedlings shortly after deployment. The sporophyte density of the direct-seeded ropes in the current experiment was among the highest in the experiment, suggesting that the direct-seeded sporophytes were not washed off the ropes after deployment but rather that extra time was needed to develop a holdfast and a tight attachment to the substrate before the frond elongation could start. The sheltered sea farm and the good light conditions at time of deployment could also have contributed to a successful attachment (Kerrison et al. 2018). A longer cultivation period, by deployment e.g. in autumn, or seeding with lower densities may have levelled out the growth between the different treatments when harvesting in June. No differences in growth measurements were found when comparing directseeded gametophytes induced in white light for 14 days to direct-seeded sporophytes cultured up to 42 days in white light. This is probably due to the low fraction of developed sporophytes in all treatments before seeding that might be the result of sub-optimal culture conditions for sporophyte development.

The rope structure and material used for seeding have proven to have a large impact on the harvesting yield. Twisted ropes have shown significantly better performance than braided ropes for both spore and juvenile sporophyte seeding (Kerrison et al. 2019). The spores and gametophytes were seeded on a twisted nylon string $(\varnothing 1.2 \mathrm{~mm}$ and wound around $\varnothing 18 \mathrm{~mm}$ twisted rope when deployed), while the treatments using a binder were seeded directly on a braided rope $(\varnothing$
$18 \mathrm{~mm}$, AlgaeRope). This dissimilarity could have impacted the final yield in this experiment and explained some of the differences.

\section{Protein content}

A decrease in protein content was measured from the first sampling in early May of $73.3 \pm 2.4 \mathrm{mg} \mathrm{g}^{-1} \mathrm{DW}$ to the second sampling in mid-June of $57.2 \pm 1.5 \mathrm{mg} \mathrm{g}^{-1}$ DW on average. The protein content most likely followed the seasonal pattern of ambient nitrate fluctuations in seawater (Rey et al. 2007; Broch et al. 2019), where a higher ambient nitrate concentration is found to result in higher protein content (Harnedy and FitzGerald 2011). Brown seaweeds have been reported to have lower protein content than green and red seaweeds, but the single maximum value found in this study $\left(111 \mathrm{mg} \mathrm{g}^{-1}\right.$ $\mathrm{DW}$ ) is within the range of some of the concentrations found in green (100-260 $\left.\mathrm{mg} \mathrm{g}^{-1} \mathrm{DW}\right)$ and red $\left(50-440 \mathrm{mg} \mathrm{g}^{-1} \mathrm{DW}\right)$ seaweeds (Fleurence 1999; Holdt and Kraan 2011). The growth environment is likely to affect the biochemical composition of seaweeds, which may, in turn, affect the quality of the harvested biomass (Kerrison et al. 2015; Schiener et al. 2015). Because the sea cultivation conditions were similar for all treatments, no large differences were expected to be found for the protein content between them. It is worth noting that the protein concentration is calculated from the nitrogen content using season- and depth-specific nitrogen-to-protein conversion factors $\left(K_{\mathrm{p}}\right)$ found in a previous experiment from the same geographical area (Forbord et al. submitted). This may both have under- and overestimated the protein concentration at certain points in time (Manns et al. 2017; Mæhre et al. 2018).

\section{Summary and conclusions}

This study has demonstrated that different seeding methods and hatchery periods had high impact on the growth performance of S. latissima at sea. Twine seeded with spores precultivated in the hatchery for 42 days gave significantly better growth measurements than any of the other treatments tested in this experiment. A clear coherence was found between days in the hatchery before deployment and growth performance at sea for the spore seeding method. In contrast, no differences were found between the hatchery period and growth at sea for the gametophytes, which indicated that the hatchery period can be reduced down to 14 days and that the induction of fertility in white light before seeding is not crucial. The gametophyte seeding showed the lowest density of all treatments at sea but had larger frond lengths, area and biomass compared to the direct-seeded treatments that used a commercial binder to attach juvenile sporophytes before deployment. All measured growth variables were poor for the direct-seeded 
treatments during the relatively short cultivation period of 120 days at sea, but a longer cultivation period might have levelled out the differences between the seeding methods. The reduced costs by skipping the hatchery phase and entwining process may make up for this in a business prospective, but no attempts were made to compare the costs related to the different seeding techniques in this work. Image analysis of substrates before deployment seemed to be a useful tool when assessing frond lengths at sea, but the method needs to be further developed to include predictions about harvesting yields. One source of weakness in this study, which might have affected the comparison of growth measurements between the seeding techniques, is the different methods used to assess seeding density. An important area for further work should be to determine the optimal seeding density for the different life stages of kelp giving the maximum yield at sea and to standardise easy methodology for measurements before deployment.

Acknowledgements This work was conducted in the Research Council of Norway with project no. 254883 (MACROSEA). Thanks to Ole Jacob Broch (SINTEF Ocean) for preparing the temperature data and designing the maps used in this paper, Magnus Oshaug Pedersen (SINTEF Ocean) for calibrating the Hobo-loggers and downloading data, and Marte Schei (SINTEF Ocean) for analysing $\mathrm{CN}$. The authors are also grateful to Åsmund Johansen (SINTEF Ocean) for helping with deployment and registrations, Synnøve Strand Jacobsen (NTNU) for registrations in field and lab, and Terje Bremvåg (SINTEF Ocean) and Bjørnar Johansen (Blått Kompetansesenter) for boat access during registrations. Thanks to the scuba diving group at NTNU for collection of sporophytes and Hortimare for providing AlgeRopes and binder for testing.

Author contributions JS conceived the idea of this study, and SF, KBS, $\mathrm{AH}$ and JS conceived and planned the article. SF, KBS and JS executed the seedling production, and SF and JS, the cultivation trials and samplings. TS was responsible for the image analysis. SF wrote the first draft of the manuscript, and all of the authors contributed to the writing/editing of the paper and approved the final manuscript.

Open Access This article is licensed under a Creative Commons Attribution 4.0 International License, which permits use, sharing, adaptation, distribution and reproduction in any medium or format, as long as you give appropriate credit to the original author(s) and the source, provide a link to the Creative Commons licence, and indicate if changes were made. The images or other third party material in this article are included in the article's Creative Commons licence, unless indicated otherwise in a credit line to the material. If material is not included in the article's Creative Commons licence and your intended use is not permitted by statutory regulation or exceeds the permitted use, you will need to obtain permission directly from the copyright holder. To view a copy of this licence, visit http://creativecommons.org/licenses/by/4.0/.

\section{References}

Alver MO, Solvang T, Kvæstad B (2018) Proof of concept on seeding system. SINTEF Ocean report 2018:00785 A,. SINTEF Ocean, Trondheim

Arbona J, Molla M (2006) Cultivation of brown seaweed Alaria esculenta. Aquaculture explained, vol 21. Bord lascaigh Mhara, Dublin
Bak UG (2019) Seaweed cultivation in the Faroe Island - an investigation of the biochemical composition of selected macroalgal species, optimised seeding techniques, and open-ocean cultivation methods from a commercial perspective. Industrial $\mathrm{PhD}$ Thesis, Technical University of Denmark, Lyngby

Bak UG, Mols-Mortensen A, Gregersen O (2018) Production method and cost of commercial-scale offshore cultivation of kelp in the Faroe Islands using multiple partial harvesting. Algal Res 33:36-47

Broch OJ, Ellingsen IH, Forbord S, Wang X, Volent Z, Alver MO, Handa A, Andresen K, Slagstad D, Reitan KI, Olsen Y, Skjermo J (2013) Modelling the cultivation and bioremediation potential of the kelp Saccharina latissima in close proximity to an exposed salmon farm in Norway. Aquacult Env Interact 4:187-206

Broch OJ, Alver MO, Bekkby T, Gundersen H, Forbord S, Handå A, Skjermo J, Hancke K (2019) The kelp cultivation potential in coastal and offshore regions of Norway. Front Mar Sci 5:529

Bruhn A, Tørring DB, Thomsen M, Canal-Vergés P, Nielsen MM, Rasmussen MB, Eybye KL, Larsen MM, Balsby TJS, Petersen JK (2016) Impact of environmental conditions on biomass yield, quality, and bio-mitigation capacity of Saccharina latissima. Aquacult Env Interact 8:619-636

CIE (2011) CIE S 017/E:2011 ILV: international lighting vocabulary. Central Bureau of the Commission Internationale de L'Éclairage, Vienna

Cottier-Cook E, Nagabhatla N, Badis Y, Campbell M, Chopin T, Dai W, Fang J, He P, Hewitt C, Kim G et al (2016) Safeguarding the future of the global seaweed aquaculture industry. United Nations University and Scottish Association for Marine Science Policy Brief 12pp

Creed JC, Kain JM, Norton TA (1998) An experimental evaluation of density and plant size in two large brown seaweeds. J Phycol 34:39 52

Cuijuan S, Hironao K, Delin D (2005) Effects of blue light on gametophyte development of Laminaria japonica (Laminariales, Phaeophyta). Chin J Oceanol Limnol 23:323

Duarte A (2017) Optimization of seedling production using vegetative gametophytes of Alaria esculenta. Master thesis, University of Porto, Porto

Ferdouse F, Holdt SL, Smith R, Murua P, Yang Z (2018) The global status of seaweed production, trade and utilization, vol 124. FAO Globefish Research Programme. Food and Agriculture Organization of the United Nations, Rome

Fleurence J (1999) Seaweed proteins: biochemical, nutritional aspects and potential uses. Trends Food Sci Technol 10:25-28

Foldal S (2018) Morphological relations of cultivated Saccharina latissima at three stations along the Norwegian coast (in Norwegian). Master's thesis, Norwegian University of Science and Technology, Trondheim

Forbord S, Skjermo J, Arff J, Handå A, Reitan K, Bjerregaard R, Lüning K (2012) Development of Saccharina latissima (Phaeophyceae) kelp hatcheries with year-round production of zoospores and juvenile sporophytes on culture ropes for kelp aquaculture. J Appl Phycol 24:393-399

Forbord S, Steinhovden KB, Rød KK, Handå A, Skjermo J (2018) Cultivation protocol for Saccharina latissima. In: Charrier BTW, Reddy C (eds) Protocols for Macroalgae Research. CRC Press, Boca Raton, pp 37-59

Fossberg J, Forbord S, Broch OJ, Malzahn AM, Jansen H, Handå A, Førde H, Bergvik M, Fleddum AL, Skjermo J, Olsen Y (2018) The potential for upscaling kelp (Saccharina latissima) cultivation in salmon-driven integrated multi-trophic aquaculture (IMTA). Front Mar Sci 5:418

Gerard V, DuBois K, Greene R (1987) Growth responses of two Laminaria saccharina populations to environmental variation. Hydrobiologia 151:229-232 
Handå A, Forbord S, Wang X, Broch OJ, Dahle SW, Størseth TR, Reitan KI, Olsen Y, Skjermo J (2013) Seasonal- and depth-dependent growth of cultivated kelp (Saccharina latissima) in close proximity to salmon (Salmo salar) aquaculture in Norway. Aquaculture 414415:191-201

Harnedy PA, FitzGerald RJ (2011) Bioactive proteins, peptides and amino acids from macroalgae. J Phycol 47:218-232

Holdt SL, Kraan S (2011) Bioactive compounds in seaweed: functional food applications and legislation. J Appl Phycol 23:543-597

Huges AP (1973) A comparison of the effects of light intensity and duration on Chrysanthemum morifolium cv. Bright Golden Anne in controlled environments: 1 Growth analysis. Ann Bot 37:267274

Kain J (1979) A view of the genus Laminaria. Oceanogr Mar Biol Annu Rev 17:101-161

Kain J (1991) Why does Delesseria sanguinea stop growing in the summer. Oebalia 17:485-492

Kain JM, Jones N (1963) Aspects of the biology of Laminaria hyperborea: II. Age, weight and length. J Mar Biol Assoc UK 43: 129-151

Kerrison PD, Stanley MS, Edwards MD, Black KD, Hughes AD (2015) The cultivation of European kelp for bioenergy: site and species selection. Biomass Bioenergy 80:229-242

Kerrison P, Stanley M, Kelly M, MacLeod A, Black K, Hughes A (2016) Optimising the settlement and hatchery culture of Saccharina latissima (Phaeophyta) by manipulation of growth medium and substrate surface condition. J Appl Phycol 28:1181-1191

Kerrison PD, Stanley MS, Hughes AD (2018) Textile substrate seeding of Saccharina latissima sporophytes using a binder: an effective method for the aquaculture of kelp. Algal Res 33:352-357

Kerrison PD, Twigg G, Stanley M, De Smet D, Buyle G, Pina AM, Hughes AD (2019) Twine selection is essential for successful hatchery cultivation of Saccharina latissima, seeded with either meiospores or juvenile sporophytes. J Appl Phycol. https://doi.org/ 10.1007/s10811-019-01793-x

Kim JK, Yarish C, Hwang EK, Park M, Kim Y (2017) Seaweed aquaculture: cultivation technologies, challenges and its ecosystem services. Algae 32:1-13

Kraan S (2013) Mass-cultivation of carbohydrate rich macroalgae, a possible solution for sustainable biofuel production. Mitig Adapt Glob Change 18:27-46

Lüning K, Dring M (1972) Reproduction induced by blue light in female gametophytes of Laminaria saccharina. Planta 104:252-256

Mæhre HK, Dalheim L, Edvinsen GK, Elvevoll EO, Jensen I-J (2018) Protein determination-method matters. Foods 7:5

Manns D, Nielsen MM, Bruhn A, Saake B, Meyer AS (2017) Compositional variations of brown seaweeds Laminaria digitata and Saccharina latissima in Danish waters. J Appl Phycol 29: 1493-1506

Marinho GS, Holdt SL, Birkeland MJ, Angelidaki I (2015) Commercial cultivation and bioremediation potential of sugar kelp, Saccharina latissima, in Danish waters. J Appl Phycol 27:1963-1973

Matsson S, Christie H, Fieler R (2019) Variation in biomass and biofouling of kelp, Saccharina latissima, cultivated in the Arctic, Norway. Aquaculture 506:445-452

Mols-Mortensen A, Ortind EG, Jacobsen C, Holdt SL (2017) Variation in growth, yield and protein concentration in Saccharina latissima (Laminariales, Phaeophyceae) cultivated with different wave and current exposures in the Faroe Islands. J Appl Phycol 29:2277-2286

Olafsen T, Winther U, Olsen Y, Skjermo J (2012) Value created from productive oceans in 2050. DKNVS and NTVA, Trondheim
Pang SJ, Lüning K (2004) Breaking seasonal limitation: year-round sporogenesis in the brown alga Laminaria saccharina by blocking the transport of putative sporulation inhibitors. Aquaculture 240:531541

Peteiro C, Freire Ó (2009) Effect of outplanting time on commercial cultivation of kelp Laminaria saccharina at the southern limit in the Atlantic coast, N.W. Spain. Chin J Oceanol Limnol 27:54

Peteiro C, Freire Ó (2013) Biomass yield and morphological features of the seaweed Saccharina latissima cultivated at two different sites in a coastal bay in the Atlantic coast of Spain. J Appl Phycol 25:205213

Provasoli L (1968) Media and prospects for the cultivation of marine algae. Proceedings of US-Japan Conference, Hakone, 12-15 September 1966: pp 63-75

Reed DC, Neushul M, Ebeling AW (1991) Role of settlement density on gemetophyte growth and reproduction in the kelps Pterygophora californica and Macrocystis pyrifera (Phaeophyceae). J Phycol 27: 361-366

Rey F, Aure J, Danielssen D (2007) Temporal and spatial distribution of nutrients. In: Sætre R (ed) The Norwegian coastal current- oceanography and climate. Tapir Academic Press, Trondheim, pp 73-88

Schiener P, Black KD, Stanley MS, Green DH (2015) The seasonal variation in the chemical composition of the kelp species Laminaria digitata, Laminaria hyperborea, Saccharina latissima and Alaria esculenta. J Appl Phycol 27:363-373

Shan TF, Pang SJ, Gao SQ (2013) Novel means for variety breeding and sporeling production in the brown seaweed Undaria pinnatifida (Phaeophyceae): crossing female gametophytes from parthenosporophytes with male gametophyte clones. Phycol Res 61:154-161

Sharma S, Neves L, Funderud J, Mydland LT, Øverland M, Horn SJ (2018) Seasonal and depth variations in the chemical composition of cultivated Saccharina latissima. Algal Res 32:107-112

Stagnol D, Macé M, Destombe C, Davoult D (2016) Allometric relationships for intertidal macroalgae species of commercial interest. J Appl Phycol 28:3407-3411

Steen H, Scrosati R (2004) Intraspecific competition in Fucus serratus and F. evanescens (Phaeophyceae: Fucales) germlings: effects of settlement density, nutrient concentration, and temperature. Mar Biol 144:61-70

Van Patten M, Yarish C (1993) Allocation of blade surface to reproduction in Laminaria longicruris of Long Island Sound (USA). Hydrobiologia 260:173-181

Wei N, Quarterman J, Jin Y-S (2013) Marine macroalgae: an untapped resource for producing fuels and chemicals. Trends Biotechnol 31: $70-77$

Wu C, Guangheng L (1987) Progress in the genetics and breeding of economic seaweeds in China. Hydrobiologia 151:57-61

Xu B, Zhang QS, Qu SC, Cong YZ, Tang XX (2009) Introduction of a seedling production method using vegetative gametophytes to the commercial farming of Laminaria in China. J Appl Phycol 21:171178

Zhang Q-S, Tang X-X, Cong Y-Z, Qu S-C, Luo S-J, Yang G-P (2007) Breeding of an elite Laminaria variety 90-1 through inter-specific gametophyte crossing. J Appl Phycol 19:303-311

Zhang QS, Qu SC, Cong YZ, Luo SJ, Tang XX (2008) High throughput culture and gametogenesis induction of Laminaria japonica gametophyte clones. J Appl Phycol 20:205-211

Publisher's note Springer Nature remains neutral with regard to jurisdictional claims in published maps and institutional affiliations. 